\title{
Programmatic actions in oral health: coping with social inequities*
}

\section{Efigênia Ferreira e Ferreira ${ }^{(a)}$ Nilce Emy Tomita ${ }^{(b)}$ Gisele da Silva Dalben ${ }^{(c)}$}

\footnotetext{
(a) Department of Public Health, School of Dentistry, Univ Federal de Minas Gerais UFMG, Belo Horizonte, MG, Brazil.

(b) Department of Pediatric Dentistry, Orthodontics and Community Health, Bauru School of Dentistry, Univ de São Paulo - USP, Bauru, SP, Brazil.

(c) Pediatric and Community Dentistry Sector, Hospital de Reabilitação de Anomalias Craniofaciais - HRAC, Univ de São Paulo USP, Bauru, SP, Brazil.
}

\begin{abstract}
Inequities are health imbalances that are avoidable, unfair and unnecessary. Studies on health inequities address the need for emergency care related to oral-dental lesions from external causes, toothache or prevalence of oral lesions, taking into account the differences between individuals and/or populations in terms of risk conditions to acquiring disease or access to health services. Inequities may be caused by the health service itself, because diseases affect socially deprived individuals more frequently and severely, especially because of multimorbidity. In the current Brazilian public health situation, programmatic actions are based on technological knowledge, especially epidemiology, focused on specific pathologies or disease risk groups, and relate closely to the organization of programmed demand. Moreover, programmatic actions should strategically use technological devices, without disregarding technical and policy flexibility, and should be closely related to inter-subjectivity and ethics, in order to develop emancipating capabilities. An action having this structure could make it easier to achieve Universality, Equity and Integrality.
\end{abstract}

Descriptors: Health Promotion; Socioeconomic Factors; Oral Health.

\section{Introduction}

Programmatic action in the field of health is defined as an organiza-

* Paper presented at the "Oral Health Under an Integrality Perspective" International Symposium, held at the $17^{\text {th }}$ Congress of the Brazilian Association for Oral Health Promotion (ABOPREV), May 31 to June 2, 2012, Salvador, BA, Brazil.

Declaration of Interests: The authors certify that they have no commercial or associative interest that represents a conflict of interest in connection with the manuscript.

Corresponding Author:

Efigênia Ferreira e Ferreira

E-mail: efigeniaf@gmail.com

Submitted: Sep 28, 2012

Accepted for publication: Oct 31, 2012

Last revision: Nov 26, 2012 tion of health work based on health integration (organization of collective work in healthcare services) and the utilization of epidemiological technologies. ${ }^{1}$ This model of action was established in order to extend coverage. It gives special attention to groups with a greater disease burden or higher risk of acquiring disease, and aims at preventing disease, and promoting and recovering health in these groups. ${ }^{2}$

In the 1970s, the precursor of programmatic actions emerged in São Paulo; it was known as Programmaction. Driven by the social security crisis, the Brazilian government began establishing measures designed to extend medical coverage to that portion of the population excluded because of noncoverage of social security. Programmaction was created with the same intention in São Paulo, i.e., as an action aimed at organizing healthcare services. Although healthcare units confirmed their engagement, Programmaction was unable to achieve the planned increase in coverage and the proposed diversification of activities, primarily due to lack of proper funding. ${ }^{1}$

In the 1980s, at the peak of the health reform movement, which ultimately led to the creation of the Brazilian Unified Public Health System 
(Sistema Único de Saúde - SUS) in 1988, new measures were implemented in Brazil. Based on the experience gained from Programmaction, the Primary Care System was conceived at the Butantã Health Center School of the Department of Preventive Medicine, University of São Paulo. ${ }^{1}$

The creation of the SUS led health policies, programs and actions to be restructured according to the institutional reform of the Brazilian health system, and was supported mainly by the principles of the SUS doctrine: universality, assuming equal access to health services and actions; equity, promoting justice; and integrality, requiring inter-sector actions and new management of public policies. ${ }^{3}$

The programmatic actions for healthcare emerged against this backdrop, and were designed to integrate collective and individual care. This integrated care system prevailed, once the existing health policies were considered ineffective because of their exclusive nature. An attempt was made at this time to recover the organizational process of collective health service work, promoting the needed dialogue between clinical actions and collective health actions. ${ }^{1}$

Bearing in mind the need to meet the doctrinal principles of SUS, programmatic actions should also contribute to organizing demand, by coordinating clinical and epidemiological rationales. Spontaneous demand (medical-centered)-a common practice in services-should co-exist with programmed demand. Moreover, programmatic action should contribute to organizing services, so as to address not only the optimization of resources and the extension of population healthcare coverage, but also the concern regarding satisfaction of individual needs. ${ }^{4}$

\section{Programmatic actions in the SUS}

Against this new Brazilian public health backdrop, programmatic actions are based on technological knowledge-especially related to epidemiology-focused on specific pathologies or disease risk groups closely related to the organization of programmed demand. The actions displaying these characteristics should be related to primary care, and combine epidemiological aspects (control of physical, biological and social environment) and clinical aspects (care to population groups), prioritizing the focus on risk. ${ }^{4}$

Bearing equal relevance, programmatic actions should strategically use technological devices without disregarding technical and policy flexibility, and should be closely related to inter-subjectivity and ethics, in order to develop emancipating capabilities. ${ }^{1}$

Figure 1 represents the conceptual scheme of programmatic action. Collective actions are integrated in healthcare, relying on epidemiology as a technological support, insofar as determinants of the disease must be coped with. The action must have an emancipative potential in order to provide the autonomy needed to control the disease, for which ethical and inter-subjective support are essential. An action with this structure could make it easier to achieve universality, equity and integrality.

The ideal scenario for programmatic actions is the Family Health Strategy (Estratégia Saúde da Família - ESF), grounded on a base of health promotion and investment in territorialization and intersectorality, and focusing on the problems of a given collectivity. For this reason, programmatic actions are combined with actions of primary healthcare, thus guiding the demand instead of simply aiming to offer a menu of actions.

\section{Inequities}

Inequities are health imbalances that are avoidable, unfair and unnecessary. ${ }^{5}$

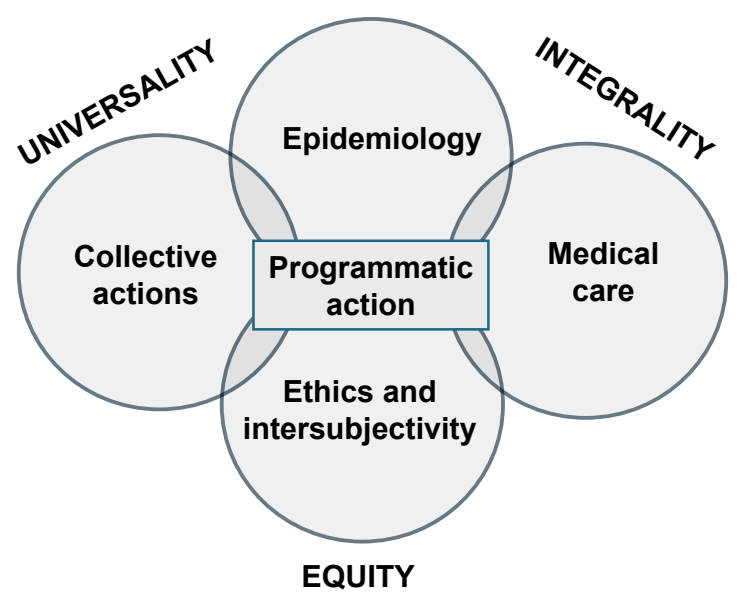

Figure 1 - Conceptual scheme of programmatic action. 
"While the difference may be acceptable from a biological or cultural point of view, imbalances and inequities are socially produced and urge us to reflect on justice". ${ }^{3}$

A recent study-covering data from 1998 to 2004-conducted in Recife on violence in adolescents aged 10-19 years indicates a higher rate of homicides (per 100,000 inhabitants) among poorer individuals (Class I, 37.47; Class II, 80.97 and Class III 86.22), and those of African descent (Class I, 89.13; Class II, 93.81 and Class III, 93.26), regardless of socioeconomic level. ${ }^{6}$ Inequalities may be accepted in the population, yet it is not possible to condone inequalities that also lead to injustice. The fact that skin color or socioeconomic conditions are determinants of homicide among adolescents is unfair and unacceptable.

Many studies have reported the occurrence of health inequities, e.g., in the case of required emergency care. Using data from the Surveillance System of Violence and Accidents (Sistema de Vigilância de Violencias e Acidentes - VIVA) from 2006 and 2007, Mascarenhas et al. ${ }^{7}$ studied emergency visits due to oral-dental lesions caused by external causes. Of 106,075 emergency visits, 939 were related to oral-dental lesions, with a higher occurrence in males $(65.5 \%)$, children under 10 years $(44.3 \%)$, individuals of African descent $(66.0 \%)$ and individuals of low educational level (45.9\%).

Pain is another phenomenon related to emergency care, and its manifestation may be an indicator of inequity. Freire et al. ${ }^{8}$ analyzed secondary data collected in the first National Survey of Schoolchildren Health (Pesquisa Nacional de Saúde do Escolar - PeNSE) on students aged 11-19 years, from 26 Brazilian capitals, from public and private schools, and studied the prevalence of toothache based on the toothache experiences reported by patients. Of the 54,985 adolescents included in the study, the prevalence of toothache was $17.8 \%$ (CI 95\%: $17.5-$ 18.1 ), ranging from $13.7 \%$ in Vitória to $22.6 \%$ in Boa Vista. The prevalence reported by the survey $(17.8 \%)$ is significant, considering that nearly 9,700 adolescents experienced toothache.

Another aspect addressed was disease prevalence, highlighting the different risk conditions of acquiring disease. In regard to dental caries, a comparison of the epidemiological surveys of $2003^{9}$ and $2010^{10}$ reveals that children aged 12 years presented different percentages, as compared to the population of healthy individuals, i.e., caries-free (Table 1). The variation is related to the macro-region of origin. The percentages presented a variation of $28 \%$ (Northern region) to $48 \%$ (Southeastern region). The existence of national policies for infants and adolescents of the Brazilian Unified Public Health System reinforces the perception of inequities, based on the variation observed.

Observing the column representing the difference between the two periods, we can notice that it ranged from $10.8 \%$ in the South to $40.7 \%$ in the Northeast. This result may be attributed to the investment made in public policies, aiming at correcting this injustice. Even though the problem may not be solved solely in this manner, it is a necessary action. In 2009 , a total of 17,641 oral health teams were established and operating in Brazil, 48.2\% $(8,508)$ in the Northeast, and $23.5 \%(4,141)$ in the Southeast.

A critical aspect concerning health inequities in Brazil is related to access. An investigation based on data collected by the Surveillance System of Risk Factors and Protection against Chronic Diseases by Telephone Inquiry (VIGITEL 2009) included nearly 26 thousand respondents who analyzed the access to health services. Of the respondents, $84.8 \%$ declared they had access to services, and only $13.2 \%$ of these were assisted by public services, whereas the majority was assisted by private services $(61.1 \%)$

Table 1 - Mean percentage (\%) of caries-free individuals, aged 12 years, in 2003 and 2010, in Brazil, according to macro-region.

\begin{tabular}{c|c|c|c}
\hline Region & 2003 & 2010 & Difference \\
\hline North & 24 & 28 & 16.6 \\
\hline Northeast & 27 & 38 & 40.7 \\
\hline Southeast & 38 & 48 & 26.3 \\
\hline South & 37 & 41 & 10.8 \\
\hline Central West & 27 & 36 & 38.7 \\
\hline Brazil & 31 & 43 & 39.7 \\
\hline
\end{tabular}

Source: Brasil, 2004; Brasil, 2011. 
and insurance systems $(22.4 \%){ }^{11}$

Inequity may be caused by the health service itself. Starfield ${ }^{12}$ indicates fundamental issues related to this possibility. First, the author highlights the need to identify inequity. Coefficients, indices and indicators are mostly presented as mean values, requiring stratification of data. The study by Mascarenhas et al., ${ }^{7}$ cited previously, presents this stratification when concluding that oral-dental lesions by external causes were more widely observed in males, children aged under ten years, individuals of African descent and individuals with a low educational level.

The second point is the access itself, which should be assured in primary care (horizontal equity) and referrals to specialized services (vertical equity). A health service that accounts for $13.2 \%$ of the demand ${ }^{11}$ may be considered an inducer of inequity per se.

The third point that must always be borne in mind is that diseases affect socially deprived individuals more frequently and severely, especially due to multimorbidity. It has been observed that specialists who prepare themselves for the mission of taking care of specific diseases are often unable to deal with the interactions of several types of diseases. The disease is aggravated by the higher probability of adverse events caused by isolated and incompatible interventions.

For these reasons, Starfield ${ }^{12}$ highlights that primary care should imperatively take on a greater importance in health systems, because it is much better to deal with multimorbidity over time.

\section{Programmatic actions and coping with inequities}

Coping with inequities by adopting programmatic actions requires a dialogic strategy, prompted by the very characteristics of these actions. Initially, we should consider the importance of integrating healthcare into collective actions. In this case, programmatic actions are adequate. Taking the data on caries-free Brazilian children ${ }^{9,10}$ as an example, the action of increasing the number of professionals involved in providing the care would be one way of coping. However, this action should be integrated into collective actions that may be specific to microspaces, or broad, as in inter-sector actions.

Programmatic actions are established on an epidemiological basis by addressing the determinants of a certain disease. They should be targeted to risk groups, and, transversally, to the programs existing in the service. As an example, a toothbrushing activity is a programmatic action that will be effective if dental caries results from deficient toothbrushing (inadequate action). If deficient toothbrushing is detected, the specific causal aspect must be determined: lack of a toothbrush, poor manual skill, life routine, or other difficulties. The integration of inter-subjectivity and ethics may lead to a successful action. Determining the cause affects the outcome.

As mentioned by Beato et al., ${ }^{13}$ it is necessary to promote dialogue between propounders of two important collective health theories, namely health surveillance and protection of life, and associate health promotion and epidemiology to the concept of an extended clinic and reception, which complement each other.

Considering a multiprofessional team as inherent to the work process of primary healthcare, programmatic actions should be developed by all players involved. Remembering what Starfield suggested, ${ }^{12}$ it is necessary to learn how to cope with multimorbidity and its interactions, not only to avoid often harmful consequences, caused by isolated and incompatible interventions, but also because man is not the sum of his organs, and their individuality and totality should be considered.

The Department of Strategic Programmatic Actions (Departamento de Ações Programáticas Estratégicas - DAPES), under the Ministry of Health, and connected to the Healthcare Agency (Secretaria de Atenção à Saúde - SAS), aims at establishing public policies based on equity, humanization and integrality of actions and services of an emancipating nature, urging the formation of networks across the three levels of healthcare: basic, medium and high complexity. ${ }^{14}$

Currently, the DAPES has been dedicated primarily to programs addressing mental health and the health of women, workers, young people and 
adolescents, children, the elderly, prisoners, and individuals with special needs and suffering from trauma and violence. As such, it provides support to expedite municipal initiatives.

\section{Conclusion}

Considering all these aspects, it may be concluded that well-planned and well-performed program-

\section{References}

1. Nemes MIB. Prática programática em saúde. In: Schraiber LB, Nemes MIB, Mendes-Gonçalves RB, organizador. Saúde do adulto: programas e ações na unidade básica. 2nd ed. São Paulo: Hucitec; 2000. p. 48-65.

2. Nascimento MS, Nascimento MAA. Prática da enfermeira no Programa de Saúde da Família: a interface da vigilância da saúde versus as ações programáticas em saúde. Cien Saude Colet. 2005 Apr-Jun;10(2):333-45.

3. Paim JS, Silva LMV. Universalidade, integralidade, equidade e SUS. Bol Inst Saude. 2010 Ago;12(2):109-14.

4. Bursztyn I. Estratégias de mudança na atenção básica: avaliação da implantação piloto do Projeto Homens Jovens e Saúde no Rio de Janeiro, Brasil. Cad Saude Publica. 2008 Oct;24(10):2227-38.

5 . Whitehead M. The concepts and principles of equity and health. Int J Health Serv. 1992;22(3):429-45.

6. Costa IER, Ludermir AB, Silva IA. Diferenciais da mortalidade por violência contra adolescentes segundo estrato de condição de vida e raça/cor na cidade do Recife. Cien Saude Colet. 2009 Dec;14(5):1781-8.

7. Mascarenhas MDM, Silva MMA, Malta DC, Moura L, Góes PSA, Moysés SJ, et al. Perfil epidemiológico dos atendimentos de emergência por lesões bucodentais decorrentes de causas externas, Brasil, 2006 e 2007. Cad Saude Publica. 2012;28 Suppl:s124-32.

8. Freire MCM, Leles CR, Sardinha LMV, Paludetto Junior M, Malta DC, Peres MA. Dor dentária e fatores associados em adolescentes brasileiros: a Pesquisa Nacional de Saúde do Escolar (PeNSE), Brasil, 2009. Cad Saude Publica. 2012;28 Suppl:s133-45.

9. Brasil. Ministério da Saúde. Secretaria de Atenção à Saúde. Departamento de Atenção Básica. Projeto SB Brasil 2003: matic actions constitute a powerful auxiliary tool for building up networks, providing viable access to services, improving the quality of provided care, and ultimately enabling the Brazilian Unified Public Health System to meet the principles of and to put into practice the healthcare precepts of Universality, Equity and Integrality of care.

condições de saúde bucal da população brasileira 2002-2003: resultados principais. Brasília (DF): Ministério da Saúde; 2004. [cited 2012 Jun 13]. Available from: http://dtr2001.saude.gov. br/editora/produtos/livros/pdf/05_0053_M.pdf.

10. Brasil. Ministério da Saúde. Secretaria de Atenção à Saúde. Secretaria de Vigilância em Saúde. Departamento de Atenção Básica. Coordenação geral de Saúde Bucal. Projeto SB Brasil 2010: pesquisa nacional de saúde bucal: resultados principais. Brasília (DF): Ministério da Saúde; 2011. [cited 2012 Jun 13]. Available from: http://189.28.128.100/dab/docs/geral/projeto_sb2010_relatorio_final.pdf.

11. Peres MA, Iser BPM, Boing AF, Yokota RTC, Malta DC, Peres KG. Desigualdades no acesso e na utilização de serviços odontológicos no Brasil: análise do Sistema de Vigilância de Fatores de Risco e Proteção para Doenças Crônicas por Inquérito Telefônico (VIGITEL 2009). Cad Saude Publica. 2012;28 Suppl:s90-100.

12. Starfield B. The hidden inequity in health care. Int J Equity Health. 2011 Apr [cited 2012 Jul 7]. Available from: http:// www.equityhealthj.com/content/10/1/15.

13. Beato MSF, Van stralen CJ, Passos ICF. Uma análise discursiva sobre os sentidos da promoção da saúde incorporados à Estratégia Saúde da Família. Interface Comun Saude Educ. 2011 Jun;15(37):529-37.

14. Brasil. Ministério da Saúde. Secretaria de Atenção à Saúde. Departamento de Ações Programáticas Estratégicas. Conheça o DAPES Brasília (DF): Ministério da Saúde; 2010 [cited 2012 Jul 7]. Available from: http://bvsms.saude.gov.br/bvs/folder/departamento_acoes_programaticas_estrategicas_dapes.pdf. 